\title{
Isolation of Bacillus spp. Bacteria from Soil for Production of Cellulase
}

Amika Ahmed Manzum and Md Arafat Al Mamun*

Pilot Plant Research Lab., Centre for Advanced Research in Sciences, University of Dhaka, Bangladesh

\begin{abstract} source of cellulase.

Keywords: Cellulase, Bacillus, isolation, API kit, shake culter.

${ }^{*}$ Corresponding Author

Email: arafat@du.ac.bd
\end{abstract}

Cellualse is one of the most important enzymes used in textile, detergent, paper, food and feed industries. Therefore, a study was undertaken to isolate Bacillus bacteria having the potential to produce cellulase from soil samples. 24 soil samples were analyzed and 54 presumptive Bacillus isolates were isolated after heating the soil samples at $80^{\circ} \mathrm{C}$ for $10 \mathrm{~min}$. Among them 45 isolates showed enzyme activity ranging from 0.003 to $0.17 \mathrm{U} / \mathrm{ml}$ in test tubes containing $5 \mathrm{ml}$ medium composed of $(\mathrm{g} / \mathrm{L})$ glucose $0.5 \mathrm{gm}$, peptone $0.75 \mathrm{gm}, \mathrm{FeSO}_{4} 0.01 \mathrm{gm}, \mathrm{KH}_{2} \mathrm{PO}_{4} 0.5 \mathrm{gm}$, and $\mathrm{MgSO}_{4} 0.5 \mathrm{gm}$ at $120 \mathrm{rpm}, 37^{\circ} \mathrm{C}$ and $\mathrm{pH}$ 7. Among them 1RW, 2WS, 3YR, 4WT, 6 RR, and 9SS showed 0.17, 0.15, 0.14, 0.15, 0.147 and $0.14 \mathrm{U} / \mathrm{ml}$ enzyme activities, respectively. Production of cellulase by these isolates was further scaled up to shake culture containing $50 \mathrm{ml}$ medium similar to that used in test tube culture. Among the isolates 1 RW showed the maximum activity. This 1 RW was identified by API kit and showed that $59 \%$ belongs to Bacillus licheniformis strain (51\% confirmation) or Bacillus subtilis ( $31 \%$ confirmation). Further gene analysis is required to confirm the species. The genetic improvement study will make the isolate a good

\section{Introduction:}

Microbial cellulases have applications in various industries including pulp and paper, textile, laundry, biofuel production, food and feed industry, brewing, and agriculture [1]. In food industry, cellulases have an important application for extraction and also clarification of juices from fruits and vegetables [2]. It is also used in the conversion of cellulosic wastes into glucose [3] and the enzymatic saccharification of lignocellulosic materials for bio-fuel production [1]. Cellulases are successfully used in textile industries for finishing of cellulose-based textiles in wet processing; in paper industries for deinking of paper wastes and in animal feed industries for pretreatment of silage and grain to increase its nutritional value [1].

Cellulase can be produced by various fungal species such as Aspergillus, Rhizopus, Trichoderma, Fusarium, Neurospora, Penicillium, etc. [4]. Production of cellulases by some bacteria such as Cellulomonas, Cellvibrio, Pseudomonas sp, Bacillus, and Micrococcus has also been reported [5]. However, bacteria with comparatively higher growth rate can potentially be used in cellulase production. Nevertheless, production of cellulase by bacteria is not widely observed.

Sometimes bacteria are preferred for large scale production of enzyme because most of them produce large amount of thermostable extracellular enzymes, which are active at a wider $\mathrm{pH}$ range [6]. Since each microbial strain is unique in their molecular, biochemical, metabolic and enzyme production properties, new strains with higher activity and unique properties are always searched to meet the demands at a commercial level [7]. Among bacteria, the Bacillus strains are most important industrial enzyme producer as they have potential for production of large amount of extracellular enzymes [8].Therefore in this study an investigation was undertaken to isolate Bacillus bacteria capable of producing cellulase enzyme.

\section{Materials and Methods} Screening and isolation of Bacillus spp. Generally the Bacillus spp. are spore former. Therefore, the major interest was isolation of the spore forming rod shaped bacteria. For this purpose the $10 \mathrm{~g}$ soil sample was diluted in $90 \mathrm{ml}$ sterile normal saline and heated at $80^{\circ} \mathrm{C}$ for 10 min to eliminate vegetative cells [9]. Cellulaseproducing bacteria were isolated by the dilution spread plate method using CMC agar media in which $\mathrm{CMC}$ was the sole carbon source. The plates were incubated at $37^{\circ} \mathrm{C}$ for 48 hours. Gram staining of the bacteria was performed. 


\section{Selection of cellulolytic bacteria}

The colonies found on the CMC agar plates were collected and a quantitative assay method was used to determine the cellulase activity of the selected bacterial isolates in liquid medium containing $(\mathrm{g} / \mathrm{L})$ glucose $0.5 \mathrm{gm}$, peptone 0.75 gm, $\mathrm{FeSO}_{4} 0.01 \mathrm{gm}, \mathrm{KH}_{2} \mathrm{PO}_{4} 0.5 \mathrm{gm}$, and $\mathrm{MgSO}_{4}$ $0.5 \mathrm{gm}$ in test tubes [5]. The cellulase activity of each culture was measured by determining the amount of reducing sugars liberated using a DNS method [10].

\section{Bacterial identification}

The assumed Bacillus sp. was identified using BioMerieux API 50 CHB/E Kit. Bacterial suspension was made with medium and each tube of the strip was then inoculated with the bacterial suspension. The bacteria fermented the carbohydrates to acids which decreased the $\mathrm{pH}$ and it was detected by the change in color of the indicator. The identification software identified the strain using the biochemical profile made up from the results. The colony selection, inoculum preparation, inoculation, incubation and interpretation of results were performed according to the manual provided by BioMerieux. The presumptive strain was determined by the software (apiweb TM) based on the results found by the API kit [11]. A positive test corresponding to acidification was indicated by the phenol red changing to yellow, except the esculin test (tube no. 25) where a change in color from red to black was observed as positive.

\section{Enzyme production medium}

Production medium contained $(\mathrm{g} / \mathrm{L})$ glucose 0.5 gm, peptone 0.75 gm, $\mathrm{FeSO}_{4} 0.01 \mathrm{gm}, \mathrm{KH}_{2} \mathrm{PO}_{4} 0.5$ gm, and $\mathrm{MgSO}_{4} 0.5 \mathrm{gm}$. $50 \mathrm{ml}$ of media were taken in $100 \mathrm{~mL}$ conical flasks. The flasks were sterilized in an autoclave at $121^{\circ} \mathrm{C}$ for $15 \mathrm{~min}$ and after cooling, the flasks were inoculated with overnight grown bacterial cultures. The inoculated media were incubated at $37^{\circ} \mathrm{C}$ and 120 $\mathrm{rpm}$ in a shaker incubator for $48 \mathrm{~h}$. After fermentation, the culture media were centrifuged at $6000 \mathrm{rpm}$ for $10 \mathrm{~min}$ and the supernatant were used as enzymes.

\section{Enzyme assay}

Cellulase activity was measured following the method of Miller (1959) [10]. Briefly, a reaction mixture composed of $0.5 \mathrm{~mL}$ of crude enzyme solution plus $1.0 \mathrm{~mL}$ of $1 \%$ carboxymethyl cellulose (CMC) in Citrate buffer ( $\mathrm{pH}$ 5.2) was incubated at $50^{\circ} \mathrm{C}$ in a shaking water bath for 30 $\mathrm{min}$. The reaction was terminated by adding $3 \mathrm{~mL}$ of DNS reagent. The color was then developed by boiling the mixture for $15 \mathrm{~min}$. OD of samples was measured at $540 \mathrm{~nm}$ against a blank containing all the reagents except the crude enzyme. One unit of cellulase is the amount of enzyme necessary to produce $1 \mu \mathrm{mol}$ reducing sugar per min under the standard assay conditions.

\section{Result and Discussion}

For rapid screening of cellulolytic bacteria, agar media containing $0.5 \% \mathrm{CMC}$ as sole carbon source are flooded with congo red after incubation. Cellulolytic colonies can be detected by observing a surrounding pale orange to clear zone against red background. The cellulolytic bacteria can be screened directly on such plate, but replica plating (each colony is inoculated onto multiple plates) from master plate is recommended because flooded reagents interfere the isolation [12]. Another procedure reported where grams iodine was used instead of congo red. Since there is poor correlation between enzyme activity and size of halo the platescreening methods using dyes are not quantitative [12]. In this study the colonies were directly selected and used for quantitative analysis of cellulase activity.

Bacillus spp. are moderately human friendly microorganisms. Various species are being used for the production of numerous industrial products such as enzymes [13], gamma polyglutamic acid [14], bacteriocin [15], biopesticides [16], waste management [17], probiotics [18] etc. One strain of Bacillus may produce different kinds of valuable products [19]. Therefore in this study the main target was the isolation of Bacillus spp. and the production of cellulase enzyme form the isolates. Since Bacillus is a spore former the isolation of this organism involved the heating of the samples at $80{ }^{\circ} \mathrm{C}$ for $10 \mathrm{~min}$ so that the vegetative cells were eliminated keeping the spores stable. Then gram positive rods were selected as presumptive 
Bacillus. 24 soil samples were investigated. After the heat treatment the bacterial load was found to
Among the isolates 1RW, 3YR, 6RR, 9SS, 2WS and $4 \mathrm{WT}$ were selected for further experiment to find out whether these strains are stable at shake flask

Table 1. Enzyme production by the presumptive Bacillus isolates.

\begin{tabular}{llllllll}
\hline Isolate & $\begin{array}{l}\text { Enzyme } \\
\text { activity } \\
(\mathrm{U} / \mathrm{ml})\end{array}$ & Isolates & $\begin{array}{l}\text { Enzyme } \\
\text { activity } \\
(\mathrm{U} / \mathrm{ml})\end{array}$ & Isolates & $\begin{array}{l}\text { Enzyme } \\
\text { activity } \\
(\mathrm{U} / \mathrm{ml})\end{array}$ & Isolate & $\begin{array}{l}\text { Enzyme } \\
\text { activity } \\
(\mathrm{U} / \mathrm{ml})\end{array}$ \\
\hline 1 RW & 0.17 & 1 SL & 0.074 & $2 \mathrm{WS}$ & 0.15 & $2 \mathrm{YR}$ & 0.124 \\
$3 \mathrm{YR}$ & 0.14 & $3 \mathrm{WS}$ & 0.11 & $4 \mathrm{WT}$ & 0.15 & $5 \mathrm{RW}$ & 0.012 \\
$5 \mathrm{SS}$ & 0.13 & $6 \mathrm{RR}$ & 0.147 & $6 \mathrm{WS}$ & 0.1 & $7 \mathrm{RW}$ & 0.026 \\
$7 \mathrm{SL}$ & 0.11 & $6 \mathrm{WS}$ & 0.1 & $7 \mathrm{RW}$ & 0.026 & $7 \mathrm{SL}$ & 0.11 \\
$7 \mathrm{SS}$ & 0 & $8 \mathrm{RW}$ & 0 & $8 \mathrm{SL}$ & 0.09 & $9 \mathrm{RW}$ & 0 \\
9 SL & 0 & $9 \mathrm{SS}$ & 0.14 & $10 \mathrm{SL}$ & 0.13 & $10 \mathrm{RW}$ & 0.016 \\
$10 \mathrm{SS}$ & 0.13 & $11 \mathrm{RW}$ & 0 & $11 \mathrm{SL}$ & 0 & $12 \mathrm{SL}$ & 0.135 \\
$12 \mathrm{RW}$ & 0.015 & $13 \mathrm{RW}$ & 0.002 & $14 \mathrm{SW}$ & 0 & $14 \mathrm{WW}$ & 0.018 \\
15 WP & 0.04 & $15 \mathrm{RW}$ & 0.05 & $15 \mathrm{SW}$ & 0.007 & $15 \mathrm{SS}$ & 0.11 \\
$16 \mathrm{RW}$ & 0 & $16 \mathrm{SW}$ & 0.035 & $17 \mathrm{RW}$ & 0.007 & $17 \mathrm{SW}$ & 0.035 \\
17 SS & 0.11 & $18 \mathrm{RW}$ & 0.004 & $18 \mathrm{SS}$ & 0.11 & $19 \mathrm{RW}$ & 0.0034 \\
19 SL & 0.018 & $20 \mathrm{RW}$ & 0.0013 & $21 \mathrm{RW}$ & 0.008 & $21 \mathrm{SS}$ & 0.01 \\
22 RW & 0.032 & $22 \mathrm{SS}$ & 0.04 & $22 \mathrm{SSp}$ & 0.045 & $23 \mathrm{RW}$ & 0.044 \\
23 RS & 0.055 & $24 \mathrm{RW}$ & 0.05 & $24 \mathrm{SS}$ & 0.043 & & \\
\hline
\end{tabular}

be lower. There were found in different types of colonies such as wrinkled large, smooth small and

smooth large colonies. All bacteria showed gram positive rod shaped results. Initially these organisms were grown in media in test tubes at $37{ }^{\circ} \mathrm{C}$ and $120 \mathrm{rpm}$ in shaking incubators. The isolates produced very low amount of enzyme showing in the Table 1.

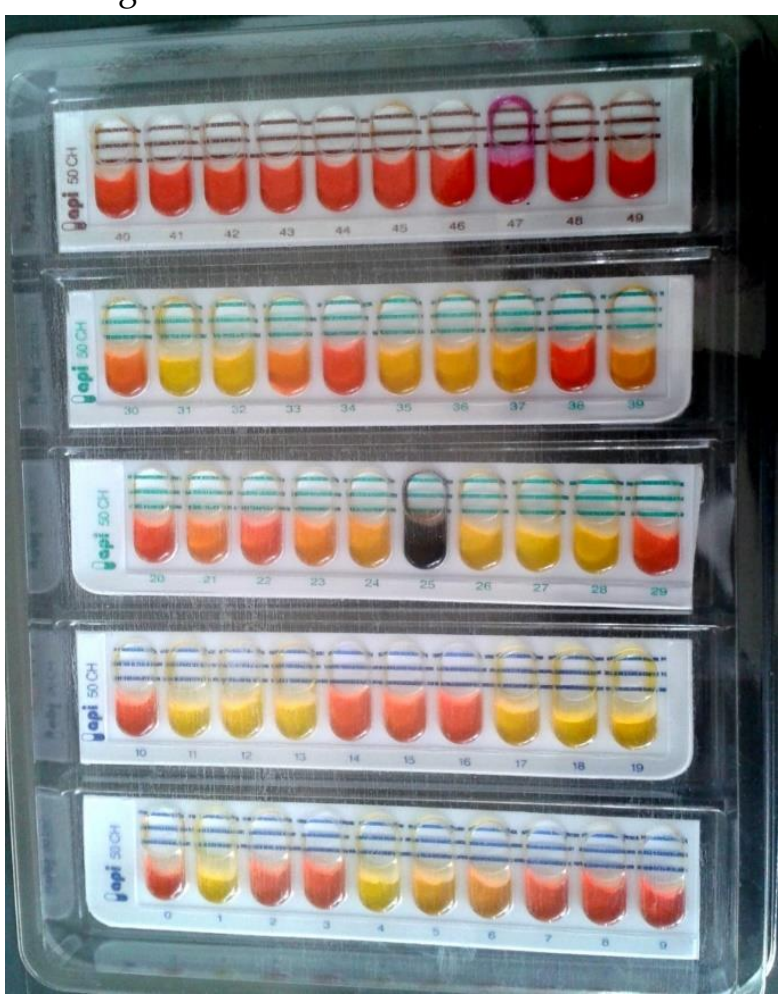

Figure 1. Biochemical test result of isolated Bacillus $\mathrm{sp}$ on API kit culture. In shake flask culture, the $1 \mathrm{RW}$ showed the maximum activity among the isolates. This type of result (enzyme activity 0.5 to $0.9 \mathrm{U} / \mathrm{ml}$ ) was reported for environmental strains such as Bacillus spp. [19-21] and Cellulomonas spp. [22]. In this study, the isolate $1 \mathrm{RW}$ was further identified by the API kit method. The results showed that the isolate belonged to the Bacillus genera and might be Bacillus licheniformis. The Figure 1 showed the biochemical reaction pattern of the isolate. Reaction 1, 4, 5, 6, 11, 12, 13, 17, 18, 19, 24, $25,26,27,28,31,32,35,36,37$ became yellow which indicated positive results. Tube number 25 designated for esculine turned black in color.

Using the software it was determined that the isolate belonged to Bacillus licheniformis $51 \%$ and Bacillus subtilis $31 \%$. The $B$. licheniformis and $B$. subtilis are genetically related [23]. These two strains are used to produce various microbial products. To remove the confusion further gene sequencing would be done. The natural strain normally produces a lower yield. Therefore further genetic improvement through mutation will be performed for 1RW. The bacteria are more suitable to produce enzyme than fungi because bacterial cellulases are more resistant to alkaline and thermophilic conditions and are good candidates for using in laundries [24]. Among the bacteria, the Bacillus spp. are more suitable because they have high growth rates, able to secrete enzymes in extracellular media and 
generally regarded as safe [8]. To improve the enzyme production yield, optimization of medium and fermentation conditions as well as genetic improvement of natural strains, are required [25].

\section{Conclusion}

In this study, Bacillus sp. has been isolated and identified using API $50 \mathrm{CHB} / \mathrm{E}$ kit. This bacteria is capable of producing cellulase in submerge culture. The Bacillus isolate would be a good source of cellulase if further investigations in terms of medium optimization and genetic improvement are performed.

\section{Acknowledgement}

The project was run by funding from Centre for Advanced Research in Sciences, University of Dhaka.

\section{Reference:}

1. Kuhad RC, Gupta R, and Singh A: Microbial Cellulases and Their Industrial Applications. Enzyme Research 2011, Article ID 280696. http:/ / dx.doi.org/10.4061/2011/280696

2. Sharma HP, Patel $\mathrm{H}$ and Sugandha: Enzymatic added extraction and clarification of fruit juices-A review. Crit Rev Food Sci Nutr 2017, 57(6):1215-1227. doi: 10.1080/10408398.2014.977434

3. Alrumman SA: Enzymatic saccharification and fermentation of cellulosic date palm wastes to glucose and lactic acid. Brazilian J Microbiol 2016, 47 (1): 110-119.

4. Sajith S, Priji P, Sreedevi S and Benjamin S: An Overview on Fungal Cellulases with an Industrial Perspective. J Nutr Food Sci 2016, 6:461. doi:10.4172/2155-9600.1000461

5. Sethi S, Datta A, Gupta BL and Gupta S: Optimization of Cellulase Production from Bacteria Isolated from Soil. ISRN Biotechnology 2013, Article ID 985685. http://dx.doi.org/10.5402/2013/985685

6. Gupta R, Beg QK and Lorenz P: Bacterial alkaline proteases: molecular approaches and industrial applications. Appl Microbiol Biotechnol 2002, 59(1):15-32.

7. Prakasham RS, Rao CS and Sarma PN: Green gram husk-an inexpensive substrate for alkaline protease production by Bacillus sp. in solid-state fermentation. Bioresource Technol 2006, 97 (13):1449 - 1454.

8. Schallmey $\mathrm{M}$, Singh $\mathrm{A}$, and Ward OP: Developments in the use of Bacillus species for industrial production. Can I Microbiol 2004, 50: 1-17. doi: 10.1139/W03-076

9. Travers RS, Martin PAW and Reichelderfer $\mathrm{CF}$ : Selective process for efficient isolation of soil Bacillus spp. Appl Env Microbiol 1987, 53 (6): 1263 - 1266.

10. Miller GL: Use of dinitrosalicylic acid reagent for determination of reducing sugar. Analytical Chemistry 1959, 31: 426-428.

11. https://www.mediray.co.nz/media/15798/o m_biomerieux_test-kits_ot-

50430_package_insert-50430.pdf

12. Farouk A-E, Banaja A, Ahamed NT, Al Zahrani $O$ and Bazaid S: Newly isolated Bacilli from Rosa damascena cv. Taifi and their evaluation for cellulose degrading efficiency. Int J Curr Microbiol App Sci 2014, 3(12): 284-295.

13. Contesini FJ, de Melo RR and Sato HH: An overview of Bacillus proteases: from production to application. Critical Reviews in Biotechnology 2018, 38(3): 321-334.

14. Chettri R, Bhutia MO and Tamang JP: Poly Glutamic Acid (PGA)-Producing Bacillus Species Isolated from Kinema, Indian Fermented Soybean. Food Front Microbiol 2016, 7: 971. doi: 10.3389/fmicb.2016.00971

15. Abriouel H, Franz CMAP, Omar N B and alvez AG: Diversityand applications of Bacillus bacteriocins. FEMS Microbiol Rev 2011, 35: 201-232.

16. Li L, Chen $\mathrm{Z}, \mathrm{Yu} \mathrm{Z}$ : Mass Production, Application and Market Development of Bacillus thuringiensisBiopesticides in China. In Bacillus thuringiensis and Lysinibacillus sphaericus. Edited by Fiuza L., Polanczyk R., Crickmore N. Springer, Cham; 2017.

17. Pangsri P: Mannanase Enzyme from Bacillus subtilis P2-5 with Waste Management. Energy Procedia 2017, 138: 343-347.

18. Elshaghabee FMF, Rokana N, Gulhane RD, Sharma $\mathrm{C}$ and Panwar $\mathrm{H}$ : Bacillus As Potential Probiotics: Status, Concerns, and Future Perspectives. Front Microbiol 2017, 8:1490. doi: 10.3389/fmicb.2017.01490

19. Kim Y-K, Lee S-C, Cho Y-Y, Oh H-J and Ko $\mathrm{Y} \mathrm{H}$ : Isolation of Cellulolytic Bacillus subtilis Strains from Agricultural Environments. ISRN Microbiol 2012. doi: $10.5402 / 2012 / 650563$

20. Patagundi BI, Shivasharan CT and Kaliwal BB: Isolation and Characterization of Cellulase producing bacteria from Soil. Int J Curr Microbiol App Sci 2014, 3(5): 59-69.

21. Singh VK and Kumar A: Production and purification of an extracellular cellulase from Bacillus brevis VS-1. Biochem Molecul Biol Int 1998, 45( 3): 243-452.

22. Irfan M, Safdar A, Syed Q, Nadeem M: Isolation and screening of cellulolytic bacteria from soil and optimization of cellulase production and activity. Turk J Biochem 2012, 37 (3): 287-293.

23. Rey MW, Ramaiya P, Nelson BA et al: Complete genome sequence of the industrial 
bacterium Bacillus licheniformis and comparisons with closely related Bacillus species. Genome Biology 2004, 5(10): Article R77.

24. Imran M, Anwar Z, Irshad M, Asad MJ and Ashfaq H: Cellulase Production from Species of Fungi and Bacteria from Agricultural Wastes and Its Utilization in Industry: A Review. Advances in Enzyme Research 2016, 4: 44-55.

http://dx.doi.org/10.4236/aer.2016.42005

25. Singh V, Haque S, Niwas R, Srivastava A, Pasupuleti $M$ and Tripathi CKM: Strategies for Fermentation Medium Optimization: An In-Depth Review. Front Microbiol 2017, 7: 2087. doi: 10.3389 / fmicb.2016.02087 